\title{
CHOOSING THE BEST MODEL FOR RESTRUCTURING BUSINESS DEBT IN INDONESIA DUE TO THE PANDEMIC USING THE ALTMAN, SPRINGATE, AND ZMIJEWSKI MODEL
}

\author{
Zainul Kisman and Riana Wuryandari \\ Trilogy University \\ DOI: http://dx.doi.org/10.38193/IJRCMS.2021.3402
}

\begin{abstract}
Financial distress is the stage of the declining financial condition of a company before bankruptcy or liquidation. This phenomenon in Indonesia in recent years shows the increasing number of companies experiencing bankruptcy. This issue needs to be investigated because there are many interested parties. This study aims to choose the best model from the Altman, Springate, and Zmijewski models to predict the level of bankruptcies in an effort to restructure the business debt of retail companies. The sample of this research is the retail sector companies listed on the Indonesia Stock Exchange for the period 2014-2018. Based on the average difference test and then calculating the level of accuracy, the result is that of the three models above, the best for predicting the level of bankruptcy is the Springate model. Therefore, this study suggests restructuring the company's business debt in the retail sector, which experiences a lot of financial distress during the pandemic using the Springate model.
\end{abstract}

KEYWORDS: Financial Distress, Altman, Springate, Zmijewski Model.

\section{INTRODUCTION}

Every company will always try to maintain its existence and sustainability both in the short and long term as well as in abnormal situations such as the current pandemic. For this reason, the company has a series of goals to be achieved, for example increasing sales, earning profits, and maximizing shareholder welfare by increasing the value of the company's shares (Kisman, 2020).

To achieve the above objectives, the company is required to always maintain and improve its competitiveness. Competitiveness will be maintained if the company continuously improves its performance and adapts to environmental developments. For companies and stakeholders, the performance can easily and simply be monitored through financial reports. So it can quickly be identified and controlled by the company. Avoid bankruptcy lest bankruptcy occurs at a level that is difficult and expensive for the company to deal with.

In the current pandemic situation, companies that are unable to maintain their financial performance will experience bankruptcy. But companies don't need to worry because bankruptcy doesn't happen 
suddenly but slowly. Then the bankruptcy can be identified through the simplest to the most sophisticated financial models available in the financial literature. So that companies or anyone can learn how companies can survive in a pandemic situation and predict through these models what corrective or restructuring actions need to be taken to maintain viability or avoid corporate bankruptcy.

Bankruptcy is a situation that is often faced by companies in the course of their business. Not only detrimental to internal parties but also external parties. According to Andriana \& Rusli (2012), the parties who are disadvantaged due to the bankruptcy of a company are company stakeholders such as investors, creditors, suppliers, and the government related to tax revenues, employment, and unemployment. Related to the many interests in this bankruptcy, this article aims to examine the validity of a model's ability to predict corporate bankruptcy. This research was conducted from a different point of view from previous studies. So that it becomes unique and interesting because of the new novelty and simplicity in its application. The novelty of this research lies in the high level of accuracy of the model offered to detect early symptoms of a company going bankrupt during a pandemic so that it can be known quickly how to control it before it is too late. Through the selection of a model that will be tested for validity and which is most in line with the reality in Indonesia and has high accuracy.

Bankruptcy (Financial distress) is a condition where the company faces financial difficulties. The financial difficulties that occurred were the accumulation of the company's operational mismanagement that took place in the long term. Because it occurs in an accumulation means that bankruptcy does not happen suddenly. Rather, it was initiated by the existence of a financial distress warning where the company experienced financial difficulties in generating sales or profits which continued to decline from year to year.

Financial experts have developed many models to predict bankruptcy as well as to solve the problem. The proposed models incorporate both internal and external factors that cause why companies need to be restructured. Some of the famous models include the Altman model, Springate model, and Zmijewski model in predicting financial distress. This study selects the retail sector as the sample that will be the object of research with the consideration that this sector experiences a greater potential for bankruptcy during a pandemic. The gloom of the retail industry throughout 2020 and 2021 due to restrictions on mobility and a decline in public consumption as a result of this sector's declining income. Moreover, the costs increase for health protocols in addition to the fixed costs that must be borne. The problem of decreasing turnover is very visible in its impact on non-food retailers compared to food. As well as large retailers compared to medium and small.

Using the three models above, namely: Altman, Springate, and Zmijewski, the purpose of this study will be to choose which model has the best validity for predicting the level of bankruptcy in Indonesia 
during a pandemic. Furthermore, the best model will identify the causes of bankruptcy and overcome them.

Based on the above background, this study will take the theme of choosing the best model to predict bankruptcy in Indonesia during the pandemic in the retail sector on the Indonesia Stock Exchange using 2014-2018 data.

\section{LITERATURE REVIEW AND DEVELOPMENT OF HYPOTHESIS.}

\section{II.1. Financial Distress}

\section{II.1.1. Definition of Financial Distress}

Financial distress is the stage of decline in the company's financial performance before the bankruptcy. According to Kisman and Krisandi (2019), financial distress is a condition in which a company faces financial difficulties. Meanwhile, according to Emery (2007) is a condition when the company experiences significant difficulties paying debts when they fall due.

Elloumi and Gueyie (2001) argue that a company is included in the category of experiencing financial distress if for two consecutive years it has a negative net profit. Meanwhile, according to Brahmins (2007), a company is categorized as a company experiencing financial distress if operating profit and net income are negative and the book value of equity is negative.

\section{II.1.2. Factors Causing Financial Distress}

According to Jauch and Glueck (1984), the factors that cause financial distress in a company are:

\section{General Factors of}

a) Economic Conditions.

The factors that cause a company to experience financial distress are inflation and deflation rates, monetary policy, interest rates, devaluation or revaluation, and balance of payments related to foreign trade.

b) Social Conditions.

Social conditions greatly affect financial distress, for example, changes in people's lifestyles that affect demand for products and services or the way companies relate to employees. Another social factor is riots or chaos that occurs in society.

c) Use of Technology.

The use of information technology causes the company's costs to swell, especially for maintenance 
and implementation. Swelling occurs, if the use of information technology is not planned by the management, the system is not integrated and the user managers are less professional. On the other hand, it will lead to savings if well planned by the company.

\section{d) Government Sector}

The influence of government policies, such as deregulation on the industry, changes in the imposition of tariffs on exports and imports of goods, deregulation related to banking or labor, and others.

\section{External Factors Company}

a) Consumer Factors

Companies must be able to identify the nature and desires of consumers to avoid losing customers. It also has the opportunity to find new customers and prevent consumers from turning to competitors.

b) Creditor factor

Obtaining soft or burdensome loan terms from creditors, repayment period of debt, competitive credit interest rates, and other facilities related to debt.

\section{c) Competitor factors}

Competitor factors are things that must be considered because they relate to customer service. Winning the competition is important because it will increase sales. On the other hand, losing the competition will cause turnover to fall. If it takes place in the long term, the company will experience financial distress.

\section{Company Internal Factors}

a) Terms of credit sales that are too lenient to customers.

b) The low efficiency of the company due to incompetent management.

c) Abuse of authority and fraud are often carried out by employees and even top managers.

\section{II.1.3 Bankruptcy Information Users}

According to Hanafi and Halim (2016), bankruptcy information is useful for several parties such as:

\section{1.) Lenders.}

This bankruptcy information can be useful for making decisions on who will be given a loan, besides that it is useful for monitoring any existing loans. Finally, it will also be useful to restructure in the event of this financial distress problem.

2.) Investors

Investors are certainly people who are very interested in seeing the possibility of bankruptcy or not the company that sells the securities. If there is a problem, it will harm investors because the value of 
the investment will decrease even if the debtor is unable to pay its obligations.

\section{3.) Management}

Management can detect bankruptcy early. Therefore, corrective actions can be taken to avoid Financial Distress.

\section{4.) Accountants}

Accountants have an interest in information on the continuity of a business because the accountant will assess the ability of going concern a company.

\section{5.) Government Parties}

In some business sectors, government agencies have the responsibility to oversee the running of the business. Government agencies have an interest in seeing signs of bankruptcy early so that necessary actions can be taken early.

\section{II.2. Prediction Models of Financial Distress}

In this section, will explain 3 bankruptcy prediction models are quite popular in the world. Namely the Altman Z-Score model, the Springate model, and the Zmijewski model.

\section{II.2.1. Altman Z-Score}

In this study, one of the analytical models to predict the potential for corporate bankruptcy is to use the Revised Altman Model (Altman, 1968). Altman's revision is an adjustment made so that this prediction model is not only for manufacturing companies that go public but can also be used for companies that have not gone public. Mathematically the Revised Altman equation can be formulated as follows:

$\mathrm{Z}=0.717 \mathrm{X} 1+0.847 \mathrm{X} 2+3.107 \mathrm{X} 3+0.420 \mathrm{X} 4+0.998 \mathrm{X} 5$

Where:

$\mathrm{X} 1=$ Net Working Capital to Total Assets.

$\mathrm{X} 2=$ Retained Earnings to Total Assets.

X3 = Earnings Before Interest and Retained Tax on Total Assets.

X4 = Book Value of Debt to Book Value of Total Debt.

$\mathrm{X} 5=$ Sales to Total Assets.

The Altman model uses the value cut off in grouping companies as follows: 
Table 2.1 The score on the Altman model

\begin{tabular}{|l|l|l|}
\hline No & Z-score & Indication \\
\hline 1 & $<1.23$ & Experiencing financial distress \\
\hline 2 & $1.23-2.9$ & Gray area \\
\hline 3 & $>2.9$ & Not experiencing financial distress \\
\hline
\end{tabular}

\section{II.2.2. Springate}

This model was discovered by Springate (1978) using the model Multiple Discriminant Analysis which is almost the same as Altman. In his method, Springate chooses 4 financial ratios. Springate formulates the model as follows:

$$
S=1.03 \mathrm{~A}+3.07 \mathrm{~B}+0.66 \mathrm{C}+0.4 \mathrm{D}
$$

Where:

1. $\mathrm{A}=$ The ratio of Working Capital to Total Assets

2. $\quad \mathrm{B}=$ The ratio of Earnings Before Interest and Taxes to Total Assets

3. $\quad \mathrm{C}=$ The ratio of Earnings Before Tax to Total Current Liabilities

4. $\quad \mathrm{D}=$ The ratio of Sales to Total Assets

For the Springate model, the value cut-off applicable is 0.862 .

Table 2.2 Score value on the Springate Model

\begin{tabular}{|l|l|l|}
\hline No & Z-score & Indication \\
\hline 1 & $<0.862$ & Experiencing financial distress \\
\hline 2 & $>0.862$ & Not experiencing financial distress \\
\hline
\end{tabular}

\section{II.2.3. Zmijewski model}

According to Sari (2014), the prediction model produced by Zmijewski (1983) is 20-year research that has been repeated. Zmijewski uses the analysis of the company's liquidity ratios, leverage, and profitability. After being tested, it shows a significant difference between healthy and unhealthy companies. Then this model produces the following equation:

$$
Z=-4.3-4.5 X_{1}+5.7 X_{2}-0.004 X_{3}
$$


Where:

$\mathrm{X}_{1}=$ Return on Assets.

$\mathrm{X}_{2}=$ Debt to Total Assets.

$\mathrm{X}_{3}=$ Current Ratio.

Table 2.3 The score on the Zmijewski model

\begin{tabular}{|l|l|l|}
\hline No & Z-score & Indication \\
\hline 1 & $>0$ & Experiencing financial distress \\
\hline 2 & $<0$ & Not experiencing financial distress \\
\hline
\end{tabular}

\section{II.4. The Research Hypothesis}

Based on the theoretical basis, relevant research, and the framework of thought, the following research hypothesis is proposed:

H1: There is a different score in predicting financial distress between the Altman model and the Springate model.

$\mathrm{H} 2$ : There is a different score in predicting financial distress between the Altman model and the Zmijewski model.

H3: There is a different score in predicting financial distress between the Springate model and the Zmijewski model.

$\mathrm{H} 4$ : There is one prediction model with the highest level of accuracy in predicting the condition of financial distress retail companies in Indonesia.

\section{III.RESEARCH METHODS}

\section{III.1. Population and Sample}

The population in this study were twenty-five Retail Industry companies listed on the Indonesia Stock Exchange (IDX) for the period 2014-2018. This study uses purposive sampling, with the following criteria, namely:

1. Retail trade sub-sector companies that are actively operating in 2014-2018. The selection of the 2014-2018 research because that period is considered a period normal.

2. Retail companies have published complete and audited financial statements for the period December 31, 2014, to December 31, 2018.

The retail companies that are sampled will be grouped into two categories, namely: 
1. For companies experiencing financial distress (hereinafter referred to as category 1 ), the criteria are:

a. Companies listed on the Indonesia Stock Exchange for the period 2014-2018.

b. Companies that publish annual financial reports in the rupiah currency.

c. Companies that publish their financial statements on the Indonesia Stock Exchange.

d. The company has a negative profit for the year for 2 consecutive years.

2. For companies experiencing non-financial distress (hereinafter given category 0), the criteria are:

a. $\quad$ Companies listed on the Indonesia Stock Exchange for the period 2014-2018.

b. Companies that publish annual financial reports in the rupiah currency

c. Companies that publish their financial statements on the Indonesia Stock Exchange.

d. The company did not experience negative current year profit for 2 consecutive years.

The sample group experiencing financial distress is 6 companies. While the group experiencing nonfinancial distress amounted to 10 companies. The annual financial statements for the 2014-2018 period are used as guidelines to determine whether the company is experiencing financial distress or nonfinancial distress.

Table 3.1 List of Sample Company Industry Retail

\begin{tabular}{|l|l|l|}
\hline No & Company Name & Ticker code \\
\hline 1 & PT Catur Sentosa Abadi Tbk & CSAP \\
\hline 2 & PT Sturdy Inti Arebama Tbk & COIN \\
\hline 3 & PT Matahari Putra Prima & MPPA \\
\hline 4 & PT Electronic City Indonesia Tbk & ECII \\
\hline 5 & PT Sona Topas Tourism Industry Tbk & SONA \\
\hline 6 & PT Sumber Alfaria Trijaya Tbk & AMRT \\
\hline 7 & PT Hero Supermarket Tbk & HERO \\
\hline 8 & PT Ramayana Lestari Sentosa Tbk & RALS \\
\hline 9 & PT Midi Utama Indonesia Tbk & MIDI \\
\hline 10 & PT Trikomsel Oke Tbk & TRIO \\
\hline 11 & PT Global Teleshop Tbk & GLOB \\
\hline
\end{tabular}




\begin{tabular}{|l|l|l|}
\hline 12 & PT Ace Hardware Indonesia & ACES \\
\hline 13 & PT Mitra Adiperkasa Tbk & MAPI \\
\hline 14 & PT Matahari Department Store Tbk & LPPF \\
\hline 15 & PT Supra Boga Lestari Tbk & RANC \\
\hline 16 & PT Tiphone Mobile Indonesia Tbk & TELE \\
\hline
\end{tabular}

Source: IDX 2014-2018

\section{III.2. Data Analysis}

\section{III.2.1. Data Analysis Techniques}

After selecting the sample and then collecting data. The next step is to perform data processing to check the normality of data. And then using paired-sample t-test or Wilcoxon Signed-rank test to check whether there is a difference significantly between each model.

\section{III.2.2. Framework for Research Analysis}

Based on the background and explanation of the variables that will be used in this study, a framework is made that describes the steps in solving problems or achieving research objectives. The steps are as follows: 
Figure 3.1 Framework for Thinking

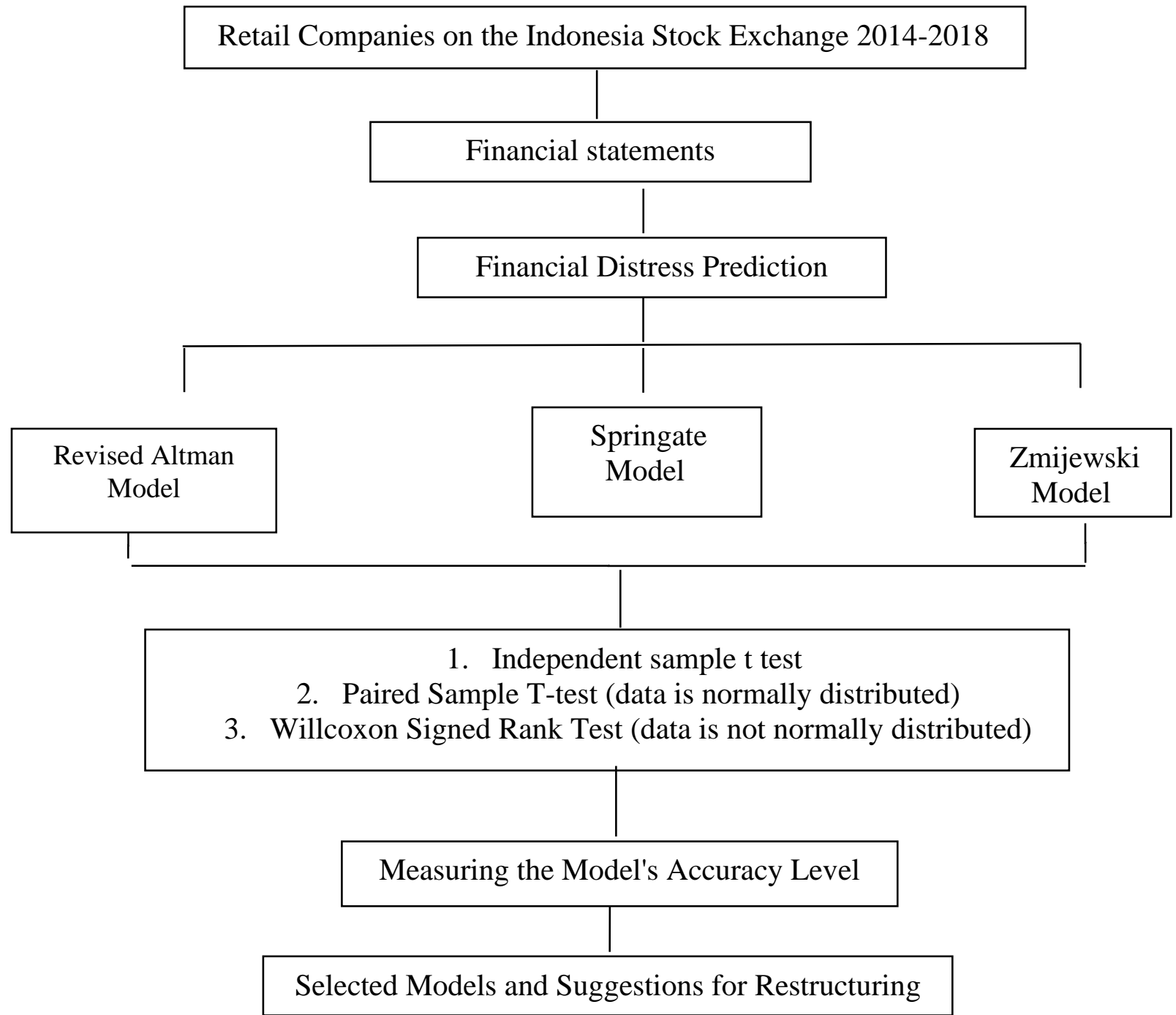

\section{RESULTS AND DISCUSSION}

\section{IV.1. Results of The Research.}

\section{IV.1.1. Normality Test}

A normality test is a requirement in conducting paired-sample t-test. This test is to see whether the data that has been collected is normally distributed or not in each of the three models, namely the revised Altman model, the Springate model, and the Zmijewski model. The sample consists of $\mathrm{N}=80$ data, each consisting of 16 retail sector companies during the 2014-2018 period. 


\section{IV.1.1.1. Normality Test of Revised Altman Model}

Figure 4.1 One-sample Kolmogorov-Smirnov test model of Revised Altman

One-Sample Kolmogorov-Smirnov Test

\begin{tabular}{|c|c|c|}
\hline & & $\begin{array}{l}\text { Unstandardiz } \\
\text { ed Residual }\end{array}$ \\
\hline N & & 80 \\
\hline \multirow[t]{2}{*}{ Normal Parameters ${ }^{a, b}$} & Mean & .0000000 \\
\hline & Std. Deviation & .00343067 \\
\hline \multirow[t]{3}{*}{ Most Extreme Differences } & Absolute & .434 \\
\hline & Positive & .275 \\
\hline & Negative & -.434 \\
\hline \multicolumn{2}{|l|}{ Test Statistic } & .434 \\
\hline \multicolumn{2}{|l|}{ Asymp. Sig. (2-tailed) } & $.000^{c}$ \\
\hline
\end{tabular}

Source: IDX 2014-2018, data processed.

The results in Figure 4.1 explain that the normality test with the One-sample Kolmogorov-Smirnov test on the normality test shows a significance value of 0.000 which means the significance value is $<0.05$ which indicates that the data is not normally distributed in the Revised Altman model.

\section{IV.1.1.2. Normality Test of Springate Model}

Figure 4.2 One sample Kolmogorov-Smirnov test Model Springate

\section{One-Sample Kolmogorov-Smirnov Test}

\begin{tabular}{|c|c|c|}
\hline & & $\begin{array}{l}\text { Unstandardiz } \\
\text { ed Residual }\end{array}$ \\
\hline N & & 80 \\
\hline \multirow[t]{2}{*}{ Normal Parameters ${ }^{a, b}$} & Mean & .0000000 \\
\hline & Std. Deviation & .00823677 \\
\hline \multirow[t]{3}{*}{ Most Extreme Differences } & Absolute & .434 \\
\hline & Positive & .413 \\
\hline & Negative & -.434 \\
\hline Test Statistic & & .434 \\
\hline Asymp. Sig. (2-tailed) & & $.000^{\circ}$ \\
\hline
\end{tabular}


In the results in Figure 4.2 explains that the normality test with the One-Sample Kolmogorov-Smirnov test on the normality test shows a value significance of 0.000 which means the significance value is $<0.05$ which means that the data is not normally distributed in the Springate model.

\section{IV.1.1.3. Normality Test of Zmijewski Model}

Figure 4.3 One sample Kolmogorov-Smirnov test Zmijewski Model

One-Sample Kolmogorov-Smirnov Test

\begin{tabular}{|c|c|c|}
\hline & & $\begin{array}{l}\text { Unstandardiz } \\
\text { ed Residual }\end{array}$ \\
\hline$N$ & & 80 \\
\hline \multirow[t]{2}{*}{ Normal Parameters ${ }^{a, b}$} & Mean & .0000000 \\
\hline & Std. Deviation & .01436830 \\
\hline \multirow[t]{3}{*}{ Most Extreme Differences } & Absolute & .482 \\
\hline & Positive & .482 \\
\hline & Negative & -.452 \\
\hline \multicolumn{2}{|l|}{ Test Statistic } & .482 \\
\hline \multicolumn{2}{|l|}{ Asymp. Sig. (2-tailed) } & $.000^{\circ}$ \\
\hline
\end{tabular}

Source: IDX 2014-2018 data processed

Figure 4.3 explains that the results of the normality test with the One-Sample Kolmogorov-Smirnov test show a significance value of $0.000<0,05$ that in the Zmijewski model the data is not normally distributed.

The condition for the parametric test is that the data must be normally distributed. Because the three models are not normally distributed, the Wilcoxon Signed-Rank Test (nonparametric test) is used for further testing.

The following are the hypotheses of the Wilcoxon test results.

$\mathrm{H}_{0}$ : There is no difference

$\mathrm{H}_{1}$ : There is a difference

The decision-making rule is if it is based on the Asym value. Sig. (2-tailed) $>0.05$, it can be seen that 
there is no difference in the model score in predicting bankruptcy in retail companies. Conversely, if the value of Asymp. Sig. (2-tailed) <0.05, it can be seen that there are differences in the model score in predicting corporate bankruptcy. The following are the output results of SPSS 24 for the hypothesis Wilcoxon Signed Rank Test different test.

\section{IV.1.2.1.1. Wilcoxon Signed Rank Test (Altman and Springate Models)}

Figure 4.4 Wilcoxon Signed Rank Test Altman and Springate models

\section{Test Statistics ${ }^{a}$}

\begin{tabular}{lr} 
& $\begin{array}{c}\text { Altman Revisi } \\
\text { - Springate }\end{array}$ \\
\hline$Z$ & $-5.540^{\mathrm{b}}$ \\
\hline Asymp. Sig. (2-tailed) & .000 \\
\hline \multicolumn{2}{|c}{ a. Wilcoxon Signed Ranks Test } \\
b. Based on negative ranks.
\end{tabular}

Source: IDX 2014-2018, data processed

Based on the results of the Wilcoxon Signed Rank Test in Table 4.4, the Sig value is known. 0.000 $<0.05$ causes Ho to be rejected and Ha to be accepted. It means that it can be concluded that there is a significant difference in the predicted score results between the Altman model and the Springate model in predicting financial distress in retail sector companies.

\section{IV.1.2.1.2. Wilcoxon Signed Rank Test (Altman and Zmijewski Models)}

Figure 4.5 Wilcoxon Signed Rank Test (Altman and Zmijewski Models)

\section{Test Statistics ${ }^{\mathrm{a}}$}

\begin{tabular}{lr} 
& $\begin{array}{c}\text { Altman Revisi } \\
- \text { Zmijewski }\end{array}$ \\
\hline$Z$ & $-5.185^{\mathrm{b}}$ \\
\hline Asymp. Sig. (2-tailed) & .000 \\
\hline
\end{tabular}

a. Wilcoxon Signed Ranks Test

b. Based on negative ranks.

Source: IDX 2014-2018, data processed. 
Based on the results of the Wilcoxon Signed Rank Test in Figure 4.5, it can be seen that the value of Sig. $0.000<0.05$ causes Ho to be rejected and Ha to be accepted. This means that it can be concluded that there is a significant difference in the predicted score results between the Altman model and the Zmijewski model in predicting financial distress in retail sector companies.

\section{IV.1.2.1.3. Wilcoxon Signed Rank Test (Springate and Zmijewski Models)}

Figure 4.6 Wilcoxon Signed Rank test (Springate and Zmijewski models)

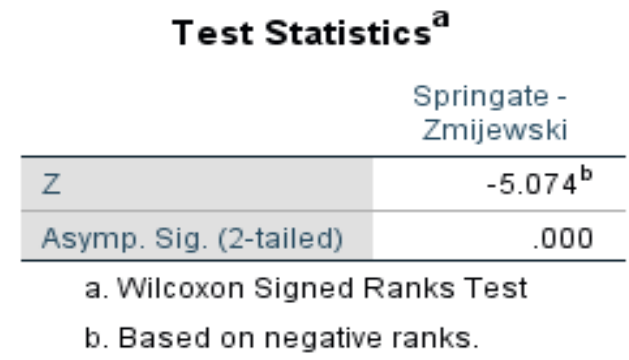

Source: IDX 2014-2018, data processed.

Based on the results of the Wilcoxon Signed Rank Test in Figure 4.6, it is known that the value of Sig. $0.000<0.05$ causes Ho to be rejected and Ha to be accepted. It can be concluded that there is a significant difference in the predicted score results between the Springate model and the Zmijewski model in predicting financial distress in retail sector companies.

\section{IV.1.2.2. Prediction Model Accuracy}

This hypothesis test is used to obtain a prediction model that has the highest level of accuracy generated in each prediction model. The level of accuracy of each model is calculated using the following method:

$$
\text { Accuracy Level }=\frac{\text { Number of } \text { Correct Predictions }}{\text { Amount of Data }} \times 100 \%
$$

For further testing results on the level of prediction accuracy will be displayed and discussed in tabular form. The following is a table and explanation for testing the accuracy of the Revised Altman model, Springate model, and Zmijewski model.

\section{Revised Altman Model}

The first level of accuracy is carried out on the Revised Altman model, here are the results of calculating the accuracy of the Altman model prediction: 
Table 4.1 Altman Model Prediction Accuracy

\begin{tabular}{|l|l|l|}
\hline Year of & $\begin{array}{l}\text { Correct } \\
\text { Prediction }\end{array}$ & Sample \\
\hline 2014 & 7 & 16 \\
\hline 2015 & 8 & 16 \\
\hline 2016 & 8 & 16 \\
\hline 2017 & 8 & 16 \\
\hline 2018 & 9 & 16 \\
\hline Total & 40 & 80 \\
\hline Accuracy & $50.00 \%$ & \\
Level & & \\
\hline
\end{tabular}

Source: IDX 2014-2018, data processed.

In Table 4.1 above, it can be seen that the Revised Altman prediction model shows a total sample calculation with 80 data, consisting of category 0 and category 1 . So the Altman model produces an accuracy rate of $50.00 \%$.

\section{Springate Model}

For the next accuracy carried out on the Springate model, the following are the results of calculating the accuracy of the Springate model prediction: 
Table 4.2 Springate Model Prediction Accuracy

\begin{tabular}{|l|l|l|}
\hline Year & $\begin{array}{l}\text { Correct } \\
\text { Prediction }\end{array}$ & Sample \\
\hline 2014 & 11 & 16 \\
\hline 2015 & 12 & 16 \\
\hline 2016 & 13 & 16 \\
\hline 2017 & 13 & 16 \\
\hline 2018 & 13 & 16 \\
\hline Total & 62 & 80 \\
\hline $\begin{array}{l}\text { Accuracy } \\
\text { Level }\end{array}$ & $77,50 \%$ & \\
\hline
\end{tabular}

Source: IDX 2014-2018, data processed.

In Table 4.2 above, it can be seen that the Springate prediction model of 80 data produces an accuracy rate of $77.50 \%$.

\section{Zmijewski Model}

Furthermore, the accuracy level is carried out for the Zmijewski model, the following are the results of calculating the prediction accuracy of the Zmijewski model: 
Table 4.3 Accuracy of Prediction of Zmijewski Model

\begin{tabular}{|l|l|l|}
\hline Year & $\begin{array}{l}\text { Correct } \\
\text { Prediction }\end{array}$ & Sample \\
\hline 2014 & 10 & 16 \\
\hline 2015 & 12 & 16 \\
\hline 2016 & 13 & 16 \\
\hline 2017 & 13 & 16 \\
\hline 2018 & 13 & 16 \\
\hline Total & 61 & 80 \\
\hline $\begin{array}{l}\text { Accuracy } \\
\text { Level }\end{array}$ & $76,25 \%$ & \\
\hline
\end{tabular}

Source: IDX 2014-2018, data processed.

In Table 4.3 above, it can be seen that the Zmijewski prediction model shows the overall calculation for 80 data, which consists of category 0 and category 1 . From the table above, the Zmijewski model produces an accuracy level $76.25 \%$.

\section{The Highest Accuracy of the Three Prediction Models}

Based on tables 4.1, 4.2, and 4.3, the comparison results of the three Altman, Springate, and Zmijewski models during 2014-2018 above can be seen that the Springate model has the highest accuracy rate of $77.50 \%$. Then the Zmijewski model is $76.25 \%$ and then the Altman Revision model is $50 \%$.

\section{IV.2. DISCUSSION}

Based on the normality test of the data (Figures 4.1, 4.2, and 4.3) it was found that the data sample was not normally distributed for the three models. This shows the high deviation of the bankruptcy score between one company and another in each model. This also illustrates the magnitude of the potential for bankruptcy in this retail sector in the period 2014-2018. Especially during a pandemic, the possibility of going bankrupt will be faster.

With the Wilcoxon Signed Rank Test (Figures 4.4, 4.5, and 4.6) it was found that there were significant differences in the results of bankruptcy prediction scores between the three models: Revised Altman, 
Springate, and Zmijewski in predicting financial distress in the retail sector companies. This illustrates that first, it is important to choose the right model. Because the results of this study prove that there is a significant difference in the average bankruptcy score between the three models. The selection of the right model will affect the level of accuracy.

In this study, when calculating the level of accuracy (Tables 4.1, 4.2, and 4.3), the Springate model which has the highest accuracy rate is $77.5 \%$, followed by the Zmijewski model of $76.25 \%$ and the Altman model revised 50\%. Using the Springate model $S=1.03 \mathrm{~A}+3.07 \mathrm{~B}+0.66 \mathrm{C}+0.4 \mathrm{D}$ to restructure retail sector companies to avoid bankruptcy, the most dominant and decisive variable is increasing the ratio of Profit Before Interest and Tax to Total Assets (B) and the ratio of Working Capital to Total Assets (A).

\section{CONCLUSION}

This study aims to identify whether or not there are differences in the values score predicted between the Altman, Springate, and Zmijewski models and to find out which model is the most accurate in predicting financial distress in retail companies listed on the Indonesia Stock Exchange in 2014-2018. It can produce some conclusions as follows:

1. From the comparison of the three prediction models are significant differences in the analysis of financial distress in retail companies listed in the Indonesia Stock Exchange (BEI) in 20142018.

2. The Springate model is the most accurate predictive model to be applied to retail companies listed on the Indonesia Stock Exchange (IDX) in 2014-2018 in restructuring their business debt due to the pandemic.

\section{REFERENCES}

Adriana, Azwir Nasir, \& Rusli (2012), Analysis of Bankruptcy Predictions Using the Springate Method in Foods And Beverages Companies Listed on the Indonesia Stock Exchange for the Period 2006-2010. Accounting Study Program, Faculty of Economics, University of Nurtanio Bandung West Java, Indonesia

Altman, E (1968). Financial Ratios Discriminant Analysis and the Prediction of Corporate Bankruptcy. The Journals of Finance, Vol.XXIII, September, 589609.

Brahmins, RK (2007). Identifying Financial Distress Conditions in Indonesia. Birmingham Business School, University of Birmingham.

Elloumi, F., \& Gueyie, J.P. (2001). Financial Distress and Corporate Governance: An Empirical Analysis. The International Journal of Business In Society.

Emery, DF (2007). Corporate Financial Management. New Jersey: Pearson Education, Inc.

Glueck, WF \& Jauch, LR (1984).Strategic Management and Business Policy. New 
York, McGraw-Hill.

Hanafi, MH, \& Halim, A. (2016). Financial Statement Analysis. Yogyakarta: UPP STIM YKPN.

Kisman, Z. (2020). The solution to overcome the disappearing dividend phenomenon: Learning from the experience of the Indonesia Stock Exchange. Cogent Economics \& Finance, 8(1), 1858566.

Kisman, Z., \& Krisandi, D. (2019). How to Predict Financial Distress in the Wholesale Sector. Journal of Economics and Business Vol.2, No.3, 569-585.

Sari, EW (2014). The Use of Zmijewski, Springate, Altman Z-Score and Grover Models in Predicting Bankruptcy in Transportation Companies Listed on the Indonesia Stock Exchange. Journal of the Faculty of Economics and Business, Dian Nuswantoro University.

Springate, Gordon LV (1978). Predicting the Possibility of Failure in a Canadian

Firm. Unpublished Master's Thesis. Simon Fraser University. January 1978.

Zmijewski, ME (1983). Predicting Corporate Bankruptcy: An Empirical Comparison of the Extant Financial Distress Models. Working Paper State University of New York, Buffalo, 